University of Nebraska - Lincoln

DigitalCommons@University of Nebraska - Lincoln

U.S. Environmental Protection Agency Papers

U.S. Environmental Protection Agency

2007

\title{
Effect of ambient particulate matter exposure on hemostasis
}

Emily Cozzi

U.S. EPA

Christopher J. Wingard

U.S. EPA

Wayne E. Cascio

U.S. EPA

Robert B. Devlin

U.S. EPA

Jeremy J. Miles

U.S. EPA

See next page for additional authors

Follow this and additional works at: https://digitalcommons.unl.edu/usepapapers

Cozzi, Emily; Wingard, Christopher J.; Cascio, Wayne E.; Devlin, Robert B.; Miles, Jeremy J.; Bofferding, April R.; Lust, Robert M.; Van Scott, Michael R.; and Henriksen, Ruth Ann, "Effect of ambient particulate matter exposure on hemostasis" (2007). U.S. Environmental Protection Agency Papers. 162.

https://digitalcommons.unl.edu/usepapapers/162

This Article is brought to you for free and open access by the U.S. Environmental Protection Agency at DigitalCommons@University of Nebraska - Lincoln. It has been accepted for inclusion in U.S. Environmental Protection Agency Papers by an authorized administrator of DigitalCommons@University of Nebraska - Lincoln. 


\section{Authors}

Emily Cozzi, Christopher J. Wingard, Wayne E. Cascio, Robert B. Devlin, Jeremy J. Miles, April R.

Bofferding, Robert M. Lust, Michael R. Van Scott, and Ruth Ann Henriksen 


\title{
Effect of ambient particulate matter exposure on hemostasis
}

\author{
EMILY COZZI, CHRISTOPHER J. WINGARD, WAYNE E. CASCIO, ROBERT B. DEVLIN, \\ JEREMY J. MILES, APRIL R. BOFFERDING, ROBERT M. LUST, MICHAEL R. VAN SCOTT, and \\ RUTH ANN HENRIKSEN
}

GREENVILLE AND RESEARCH TRIANGLE PARK, NC

\begin{abstract}
Epidemiological studies have linked levels of particulate matter (PM) in ambient air to cardiovascular mortality and hospitalizations for myocardial infarction (MI) and stroke. Thrombus formation plays a primary role in potentiating acute cardiovascular events, and this study was undertaken to determine whether pulmonary exposure to PM alters hemostasis. PM was collected from the Chapel Hill, NC airshed and was administered to mice by intratracheal instillation at a dose previously shown to exacerbate myocardial ischemia-reperfusion injury. Twenty-four hours after exposure, an increase occurred in the number of circulating platelets and plasma concentrations of fibrinogen and soluble P-selectin. The concentration of tissue factor pathway inhibitor (TFPI) in plasma was decreased, whereas the plasma concentration of plasminogen activator inhibitor (PAI-1) was increased. Consistent with these observations, bleeding time from a tail-tip transection was shortened. These results provide evidence that PM exposure alters hemostasis in otherwise healthy animals and may thereby promote clot formation and impede clot resolution in susceptible individuals. The results also establish definite hemostatic endpoints that can be used to further investigate the effects of dose and particle characteristics on the toxicity of ambient particles. (Translational Research 2007;149:324-332)
\end{abstract}

\begin{abstract}
Abbreviations: $\mathrm{CBC}=$ complete blood count; ELISA = enzyme-linked immunosorbent assay; ICR = Institute for Cancer Research; $\mathrm{Ml}=$ myocardial infarction; PAI-1 = plasminogen activator inhibitor; PBS = phosphate-buffered saline; $\mathrm{PM}=$ particulate matter; $\mathrm{SE}=$ standard error; $\mathrm{sP}$ selectin = soluble P-selectin; TAT $=$ thrombin/antithrombin; TF $=$ tissue factor; TFPI = tissue factor pathway inhibitor; IPA = tissue-type plasminogen activator; US-EPA = United States Environmental Protection Agency
\end{abstract}

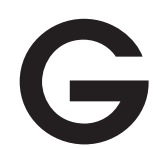
lobal epidemiological studies have linked ambient particulate matter (PM) exposure to cardiac arrhythmia, myocardial infarction (MI), cardiac arrest, heart failure, and mortality because of ischemic heart disease. ${ }^{1-3}$ Empirical evidence collected over the past decade also indicates that airborne

From the Department of Physiology and the Department of Internal Medicine, Brody School of Medicine at East Carolina University, Greenville, NC, and the National Health and Environmental Effects Research Laboratory, US-EPA, Research Triangle Park, NC.

Supported in part by a grant from Philip Morris USA and Philip Morris International (\#567881) and a predoctoral fellowship from the Mid-Atlantic Affiliate of the American Heart Association (\#0615380U).
PM can affect cardiovascular function and may thereby contribute to the pathogenesis of cardiovascular disease. $^{4-12}$

Ambient PM comprises a heterogeneous mixture of substances, including carbon, metals, nitrates, sulfates, organic compounds, and components of biogenic ori-

Submitted for publication September 14, 2006; revision submitted December 8, 2006; accepted for publication December 12, 2006.

Reprint requests: Michael R. Van Scott, PhD, Department of Physiology, Brody School of Medicine, East Carolina University, 6N98 Brody Building, Greenville, NC 27834. e-mail: vanscottmi@ecu.edu. 1931-5244/\$ - see front matter

(C) 2007 Mosby, Inc. All rights reserved.

doi:10.1016/j.trsl.2006.12.009 
gin. ${ }^{13,14} \mathrm{PM}$ is derived from several different sources, including combustion products from gasoline and diesel engines, coal- and oil-fired power plants, biomass burning (eg, fireplaces and forest fires), and natural sources such as wind-blown dust or crushing of crustal materials. ${ }^{13,15-18}$ The US-EPA, currently regulates PM levels on the basis of mass in 2 size ranges: "coarse" PM (2.5-10 microns in diameter) and "fine" PM (0.12.5 microns in diameter). ${ }^{13}$ However, increasing attention is being placed on smaller "ultrafine" particles, with a diameter of less than 0.1 micron. ${ }^{13}$ Although these particles contribute very little to PM mass, they dominate particle number and surface area metrics. ${ }^{13,19}$ Furthermore, some have suggested that these smaller particles can more readily exit the lung, where they may directly affect cells and organs of the cardiovascular system. ${ }^{20}$

Inhalation of PM has been shown to activate pulmonary endothelium, macrophages, and neutrophils. ${ }^{21-23}$ Pulmonary inflammation acts as a catalyst for subsequent systemic inflammation. ${ }^{21,22,24}$ Studies in humans and animals have demonstrated that PM increases the release of neutrophils from bone marrow and the number of subsequently circulating neutrophils. ${ }^{19,25}$ Relocation from an environment with high PM levels to one with negligible PM reverses this effect. ${ }^{26} \mathrm{PM}$ exposure has also been shown to increase C-reactive protein expression, plasma viscosity, and the progression of atherosclerotic lesions. ${ }^{13,22,27-30}$ Furthermore, exposure to concentrated ambient particles has been associated with increased oxidative stress, altered vascular reactivity, and alterations in hemostasis, which are strongly associated with adverse cardiovascular effects. ${ }^{10,31-34}$

Recent studies indicate that exposure to PM also promotes thrombus formation. Nemmar et $\mathrm{al}^{20}$ have shown that PM from diesel exhaust activates platelets and promotes femoral venous thrombosis in a dosedependent manner in hamsters. Likewise, Radomski et $\mathrm{al}^{35}$ observed that exposure to carbon particles augmented thrombosis in rats. Addition of these particles directly to human platelets induced platelet aggregation via adenosine 5'-diphosphate-, matrix metalloproteinase-, or protein kinase C-dependent pathways. ${ }^{35}$ This study was undertaken to elucidate effects of ambient particulate matter on systemic factors involved in hemostasis and thereby to define discrete endpoints that can be used to further investigate the toxicity of airborne particles.

\section{MATERIALS AND METHODS}

Animals. For this study, 6- to 10-week-old male Institute for Cancer Research (ICR) mice were obtained from Harlan (Indianapolis, Ind), housed in microisolation, and cared for by the East Carolina University Comparative Medicine staff. All protocols conformed to the standards in the National Institutes of Health's "Guide for the Care and Use of Laboratory Animals" and were approved by the East Carolina University Institutional Committee on the Care and Use of Laboratory Animals.

Particle collection and extraction. Particles were collected as described by Cozzi et al. ${ }^{10}$ Briefly, particles were collected over 7-day periods, during October 2002, in Chapel Hill, NC with a ChemVol High Volume Cascade Impactor (Rupprecht and Patashnick Co., Inc., East Greenbush, NY). Particles (less than $0.15 \mu \mathrm{m}$ in diameter) were collected onto G5300 filters (Monandock Non-Wovens LLC, Mt. Pocono, Penn), dried under sterile conditions, and stored at $-80^{\circ} \mathrm{C}$ until extracted. Particles were extracted by prewetting the filter with $70 \%$ ethanol, and endotoxin-free water was added to yield a total volume of $40 \mathrm{~mL}$. Extraction efficiency was $65-70 \%$. The substrate-water solution was sonicated, and the particle extract was concentrated by lyophilization and stored at $-80^{\circ} \mathrm{C}$. Extracts were reconstituted to a concentration of 5 $\mathrm{mg} / \mathrm{mL}$ in water and stored at $-80^{\circ} \mathrm{C}$. Four consecutive weeks of extracts were pooled into monthly batches. These particles exhibit a total carbon mass fraction of just over $22 \%$; high levels of arsenic, bromide, selenium, sulfur, and zinc; and low levels of iron and titanium (unpublished data). Particle endotoxin levels were measured with a chromogenic limulus amebocyte lysate endpoint assay (QCL-1000; Cambex, Rockland, Me) according to kit instructions. No detectable levels of endotoxin were found on the particles.

Particulate exposure. Mice were exposed to PM as described by Cozzi et al. ${ }^{10}$ Briefly, mice were anesthetized with vapors from isoflurane/propanediol and a suspension of $100 \mu \mathrm{g}$ of PM in $100 \mu \mathrm{L}$ of sterile phosphate-buffered saline (PBS) (composition in mM: $\mathrm{NaCl}, 137 ; \mathrm{NaH}_{2} \mathrm{PO}_{4}, 10 ; \mathrm{KH}_{2} \mathrm{PO}_{4}, 1.47$; $\mathrm{KCl}, 2.7$; $\mathrm{pH}$ adjusted to 7.4) was prepared and delivered by intratracheal instillation. This dose of PM was previously shown to elicit pulmonary and cardiovascular effects in ICR mice. ${ }^{10}$ Vehicle-exposed mice received $100 \mu \mathrm{L}$ of sterile PBS.

Complete blood count (CBC). Twenty-four hours after exposure, a cardiac blood draw was performed in mice euthanized by intraperitoneal injection of sodium pentobarbital as adapted from Hoff et al. ${ }^{36}$ Blood was drawn to a total volume of $1 \mathrm{~mL}$ using a 25-gauge needle attached to a 1-mL syringe containing $100 \mu \mathrm{L}$ of $3.8 \%$ sodium citrate as an anticoagulant. A CBC was determined on whole blood using a Coulter Counter (Beckman Coulter, Fullerton, Calif). Cell counts were corrected for anticoagulant dilution, averaged between groups, and reported.

Platelet/monocyte interaction. Blood collected $24 \mathrm{~h}$ after exposure from a separate set of mice was placed in $\mathrm{PGE}_{1}-\mathrm{K}_{2}$ EGTA anticoagulant tubes and then divided for subsequent analyses. For flow cytometry analysis of CD41, red blood cells were lysed by adding Optilyse C (Beckman Coulter) in a $1: 1$ ratio and $50 \mu \mathrm{L}$ of the blood/Optilyse $\mathrm{C}$ solution was incubated with a fluorescent-conjugated antibody against CD41 (anti-mouse CD41-FITC; BD Biosciences, San Jose, Calif) or a matched isotype control anti-

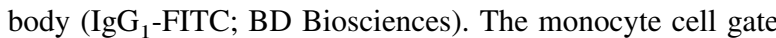
was determined by forward- and side-scatter parameters. Flu- 
orescence within this gate was analyzed by flow cytometry (FACScan; Becton Dickinson, San Jose, Calif), and mean fluorescence intensity was calculated and reported.

Plasma fibrinogen levels. Whole blood remaining after $\mathrm{CBC}$ analyses was centrifuged at $5000 \mathrm{~g}$ for $10 \mathrm{~min}$, and plasma was removed. Plasma fibrinogen levels in fresh plasma were determined by a modified thrombin time as described by Clauss et al. ${ }^{37}$ Briefly, $100 \mu \mathrm{L}$ of diluted plasma was incubated at $37^{\circ} \mathrm{C}$ within the Coag-A-Mate $\mathrm{XM}$ coagulation timer (Biomerieux, Durham, NC) before the addition of $100 \mu \mathrm{L}$ of Fibriquik thrombin reagent (Biomerieux) to induce coagulation. Clotting times were converted to fibrinogen level based on a human fibrinogen standard curve. Mean fibrinogen levels for each mouse group were calculated and reported.

Plasma thrombin/antithrombin (TAT) levels. Twenty-four hours after exposure, plasma TAT complex concentrations were determined with a human TAT complex-specific sandwich enzyme-linked immunosorbent assay (ELISA) known to cross-react with mouse TAT antigen according to kit instructions (Enzygnost kit; Dade Behring, Marburg, Germany). ${ }^{38,39}$ Briefly, $50 \mu \mathrm{L}$ of citrated plasma were incubated in 96 well plates coated with human thrombin-specific antibody. After addition of a peroxidase conjugated antibody to human antithrombin and color development, the optical density of the plate was read at $492 \mathrm{~nm}$ using a spectrophotometer (SmartSpec 3000; Bio-Rad, Hercules, Calif). A negative control containing sample buffer was also used to establish a background spectrophotometer reading at $492 \mathrm{~nm}$, which was subtracted from sample readings, and TAT complex concentrations were determined based on a human TAT complex standard curve $(2-60 \mathrm{ng} / \mathrm{mL})$ supplied with the kit. Mean plasma TAT concentrations were calculated and reported.

ELISAs for plasma soluble P-selectin (sP-selectin), plasma tissue factor pathway inhibitor (TFPI), plasma tissue-type plasminogen activator (TPA), and plasminogen activator inhibitor (PAI-1). Blood collected via cardiac puncture was placed in collection tubes containing 7.5\% ED$\mathrm{TA}\left(\mathrm{K}_{3}\right)$ anticoagulant (Kendall Monoject $10.25 \times 50 \mathrm{~mm}$; Tyco Healthcare Group LP, Mansfield, Mass) and centrifuged at $5000 \mathrm{~g}$ for $10 \mathrm{~min}$ to obtain plasma. Plasma sP-selectin, tPA, and PAI-1 concentrations were determined by using commercially available ELISA kits according to the manufacturers' instructions (Quantikine kit; R\&D systems, Minneapolis, Minn; Molecular Innovations, Southfield, Mich). Plasma TFPI concentrations were determined by coating 96 well plates with 1:20 diluted plasma in $1 \%$ bovine serum albumin in PBS. Rabbit anti-mouse TFPI IgG (1:500; American Diagnostica, Inc., Stamford, Conn), goat anti-rabbit IgG peroxidase conjugate (1:12,000; Sigma-Aldrich, St. Louis, Mo), and 3,3' 5,5' Tetramethylbenzidine substrate reagent (BD Biosciences) were used for detection. Plate absorbance was measured at $450 \mathrm{~nm}$ using a microplate reader (Benchmark Microplate Reader; Bio-Rad). Specificity of the antiTFPI antibody was confirmed by immunoprecipitation as described by Michielsen et al. ${ }^{40}$

Bleeding time determination by tail-tip transaction. Analysis of bleeding from an induced injury was conducted as described by Sato et al. ${ }^{41}$ Twenty four hours after exposure, mice were anesthetized with sodium pentobarbital $(50 \mathrm{mg} / \mathrm{kg}$ initial dose, $30 \mathrm{mg} / \mathrm{kg}$ if supplemental doses were needed), and tail-tips, $5 \mathrm{~mm}$ from their distal end, were surgically transected using a scalpel blade. Tails were immediately placed in a tube containing $10 \mathrm{~mL}$ of saline warmed to $37^{\circ} \mathrm{C}$, and a timer was started. The bleeding time was recorded as the time required for initial stoppage of blood flow. Average bleeding times were calculated and reported for each mouse group. Overall, 20 min after tail transection, blood collected in saline was hemolyzed and the absorbance at $546 \mathrm{~nm}$ was used to determine blood volume loss.

Statistics. Values were reported as mean \pm standard error (SE). Differences between groups were compared using the Student $t$-test for unpaired observation or analysis of variance with the Fisher exact test for least significant difference. In all cases, a $P$ value of less than 0.05 was used to indicate statistical significance between groups.

\section{RESULTS}

Particulate matter effects on circulating blood cell counts. Total leukocyte counts decreased $24 \mathrm{~h}$ after PM exposure (vehicle, $5620 \pm 310$ cells $/ \mathrm{mL}$ whole blood; PM, $4608 \pm 331$ cells $/ \mathrm{mL}$ whole blood; $P=0.026$ ). These results were consistent with previous findings and confirmed effective delivery of PM. ${ }^{10}$ It should be noted that, in some animal studies, increases in circulating polymorphonuclear cells with PM exposure have been reported. $^{22,42}$ For shorter time intervals after PM exposure, it has been reported that circulating neutrophils enter the lungs, which could explain the reduction in total leukocyte counts observed. ${ }^{43}$

In contrast, circulating platelet numbers in exposed mice increased slightly compared with vehicle controls (Fig 1, A). As PM exposure did not alter circulating RBC number (vehicle, 818,400 $\pm 168,465$ cells $/ \mathrm{mL}$ whole blood; PM, 824,333 $\pm 139,081$ cells $/ \mathrm{mL}$ whole blood; $P=0.43$ ), hemoglobin (vehicle, $13.1 \pm 0.3 \mathrm{~g} / \mathrm{dL} ; \mathrm{PM}$, $13.1 \pm 0.2 \mathrm{~g} / \mathrm{dL} ; P=0.95$ ), or hematocrit (vehicle, $41.4 \pm 1.0 \%$; PM, $41.8 \pm 0.9 \% ; P=0.39$ ), the results indicate specific effects on neutrophils and circulating platelets.

Effect of particulate matter on platelet and endothelial activation. sP-selectin may be released by both activated platelets and endothelial cells. ${ }^{4,45} \mathrm{PM}$ exposure significantly increased plasma sP-selectin levels $24 \mathrm{~h}$ after exposure (Fig 1,B). Interaction of platelets and monocytes was examined as a more specific indicator of platelet activation. ${ }^{46}$ Platelets were labeled with a fluorescent-conjugated antibody specific for mouse platelet glycoprotein IIb (CD41), and association with monocytes was then analyzed by flow cytometry. PM exposure did not alter the number of CD41-positive platelets within the monocyte gate (Fig 2), indicating that PM exposure did not increase binding between platelets and monocytes. 

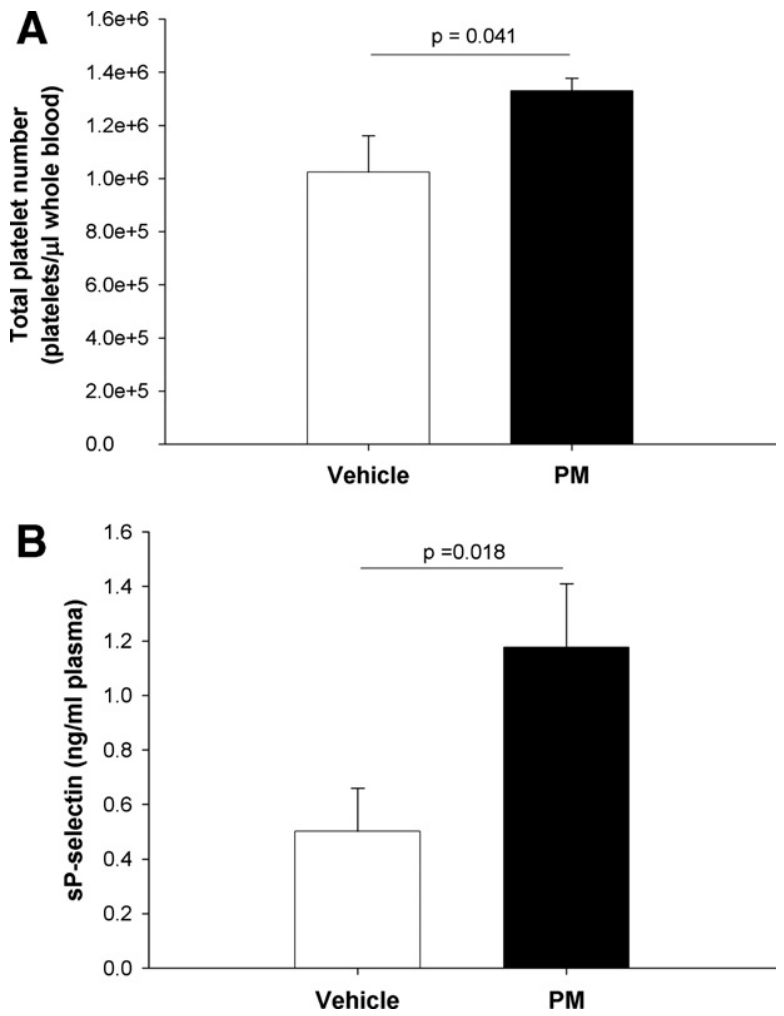

Fig 1. Total platelet number and plasma sP-selectin levels $24 \mathrm{~h}$ after exposure. Mice were exposed to vehicle or $100 \mu \mathrm{g}$ of PM by intratracheal instillation. (A) Blood was drawn via cardiac puncture $24 \mathrm{~h}$ after exposure, and a CBC was performed on each whole-blood sample. Values represent mean platelet numbers $\pm \mathrm{SE}, \mathrm{n}=11$ vehicle control and $\mathrm{n}=9$ PM exposed animals. (B) Blood was drawn via cardiac puncture $24 \mathrm{~h}$ after exposure, and plasma was prepared and assayed with a commercially available mouse specific sP-selectin ELISA kit. Values represent mean $\pm \mathrm{SE}, \mathrm{n}=6$ in each group, repeated in duplicate.

Effect of particulate matter on circulating coagulation proteins. Fibrinogen is the soluble precursor of fibrin, which plays a central role in platelet aggregation and clot formation. ${ }^{47}$ Plasma fibrinogen levels from blood samples obtained via cardiac puncture $24 \mathrm{~h}$ after PM or vehicle exposure were significantly increased compared with the vehicle control group (Fig 3).

Thrombin is a serine protease that not only converts soluble fibrinogen into insoluble fibrin, but also it promotes platelet aggregation during clot formation. ${ }^{48}$ Thrombin activity is inhibited when antithrombin binds irreversibly to thrombin forming a TAT complex. ${ }^{49}$ As thrombin is the terminal protease in the coagulation cascade, analysis of TAT complex concentrations within the plasma serves as an indication of coagulation pathway activation. ${ }^{50}$ Plasma TAT concentrations were unchanged $24 \mathrm{~h}$ after PM exposure (Fig 4), indicating the lack of ongoing thrombin generation.

TFPI, a glycoprotein released by endothelial cells,
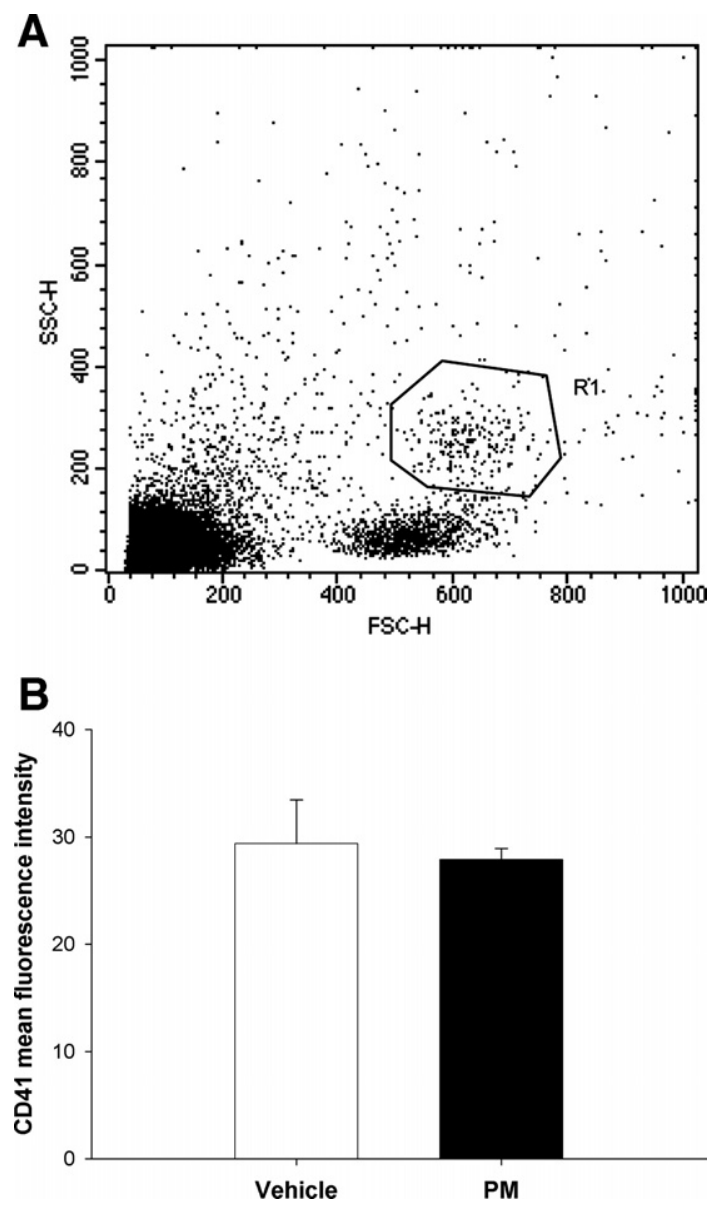

Fig 2. Circulating platelet/monocyte interaction $24 \mathrm{~h}$ after PM or vehicle exposure. Blood was drawn via cardiac puncture $24 \mathrm{~h}$ after exposure. Platelets in each whole-blood sample were labeled with a mouse-specific fluorescent-conjugated antibody against CD41. (A, gate R1) Flow cytometry was performed, and the monocyte population was gated based on forward and side scatter properties. (B) CD41 represents mean florescence intensity within the monocyte gate. Values represent mean $\pm \mathrm{SE}, \mathrm{n}=6$ in each group, repeated in duplicate.

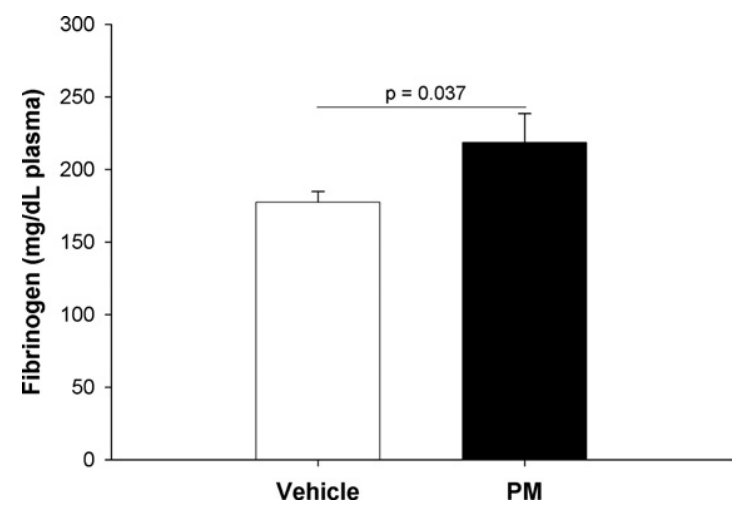

Fig 3. Plasma fibrinogen levels $24 \mathrm{~h}$ after PM or vehicle exposure. Blood was drawn via cardiac puncture $24 \mathrm{~h}$ after exposure, and plasma was prepared. Plasma fibrinogen levels were determined by a modified thrombin time. Values represent mean fibrinogen concentrations \pm SE, $\mathrm{n}=11$ vehicle control and 9 PM exposed animals. 


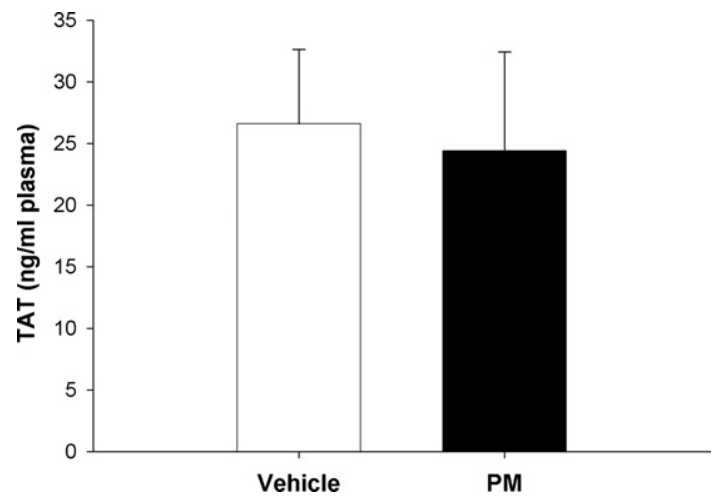

Fig 4. Plasma TAT concentrations $24 \mathrm{~h}$ after vehicle or PM exposure. Blood was drawn via cardiac puncture $24 \mathrm{~h}$ after exposure, and plasma was prepared. TAT plasma concentrations were determined with a commercially available ELISA kit. Values represent mean TAT concentrations $\pm \mathrm{SE}, \mathrm{n}=10$ in each group.

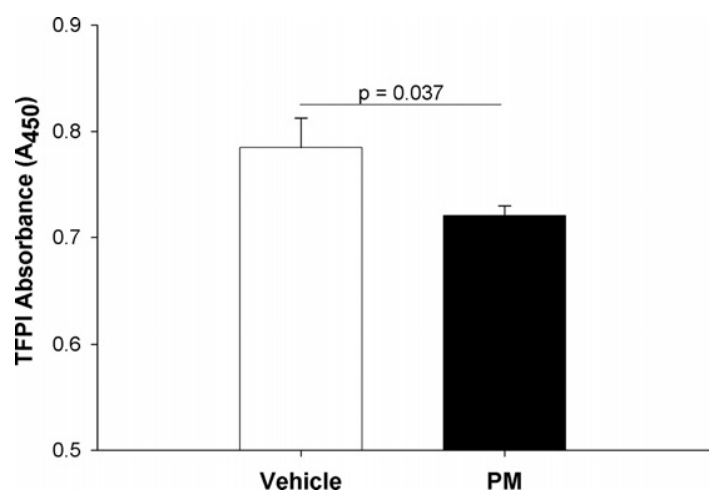

Fig 5. Plasma TFPI absorbance $24 \mathrm{~h}$ after vehicle or PM exposure. Blood was drawn via cardiac puncture $24 \mathrm{~h}$ after exposure, and plasma was prepared. TFPI concentrations were determined by sandwich ELISA. Values represent mean TFPI concentration $\pm \mathrm{SE}, \mathrm{n}=$ 7 vehicle control and 6 PM exposed animals, repeated in triplicate.

inhibits TF-initiated clotting by binding factor $\mathrm{Xa}$ and the TF/VIIa complex, thus inhibiting subsequent thrombin production. ${ }^{51,52}$ Plasma TFPI levels were decreased significantly $24 \mathrm{~h}$ after PM exposure when compared with vehicle control (Fig 5).

Effect of particulate matter on the fibrinolytic pathway. Tissue-tPA converts plasminogen into the active protease plasmin, which leads to degradation of fibrin and subsequent vascular thrombus dissolution. ${ }^{53} \mathrm{PM}$ exposure did not change circulating tPA levels $24 \mathrm{~h}$ after exposure (Fig 6, A). PAI-1 is a member of the serine protease inhibitor family and is the primary inhibitor of tPA. ${ }^{54}$ Thus, PAI-1 serves to inhibit fibrinolysis and clot dissolution. PM exposure significantly increased circulating PAI-1 levels above vehicle $24 \mathrm{~h}$ after exposure (Fig 6, B).
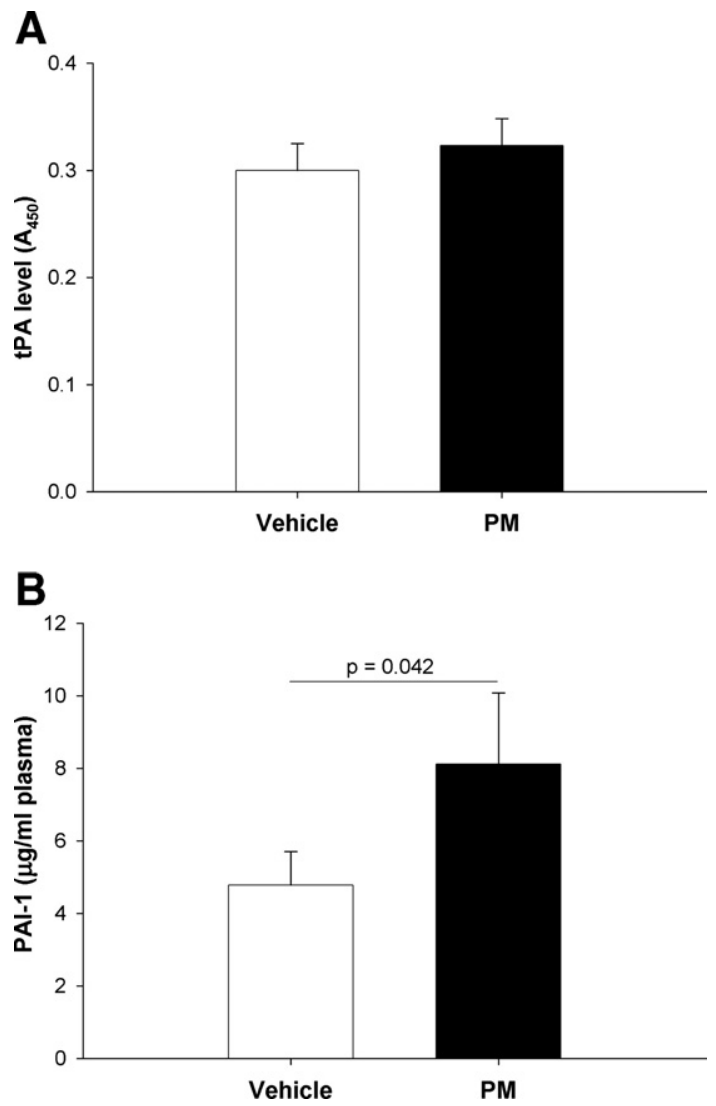

Fig 6. Plasma tPA absorbance and PAI-1 concentrations $24 \mathrm{~h}$ after vehicle or PM exposure. Blood was drawn via cardiac puncture $24 \mathrm{~h}$ after exposure, and plasma was prepared. Tissue plasminogen activator concentrations were determined with a commercially available ELISA kit and mean sample absorbance \pm SE is shown, assays repeated in duplicate, $\mathrm{n}=21$, vehicle control and 17 PM exposed animals (A). PAI-1 concentrations were determined with a commercially available ELISA kit (B). Values represent mean PAI-1 concentrations $\pm \mathrm{SE}, \mathrm{n}=13$ vehicle control and 8 PM exposed animals, repeated in duplicate.

In vivo analysis of particulate matter exposure on hemostasis. In mice, the length of time that blood flows from an induced vascular injury is indicative of the levels of coagulation factors as well as of platelet and endothelial activity. ${ }^{55}$ Bleeding time from a tail-tip transection was therefore assessed as an in vivo indicator of hemostasis. Mice were exposed to PM or vehicle, and $24 \mathrm{~h}$ after exposure, tail-tips were transected and bleeding times were measured. Bleeding times were significantly shortened after PM exposure when compared with vehicle controls (Fig 7), indicating that the propensity for clot formation was enhanced. The total blood loss $20 \mathrm{~min}$ after tail-tip transection was not significantly different between PM exposed and control groups (results not shown). 


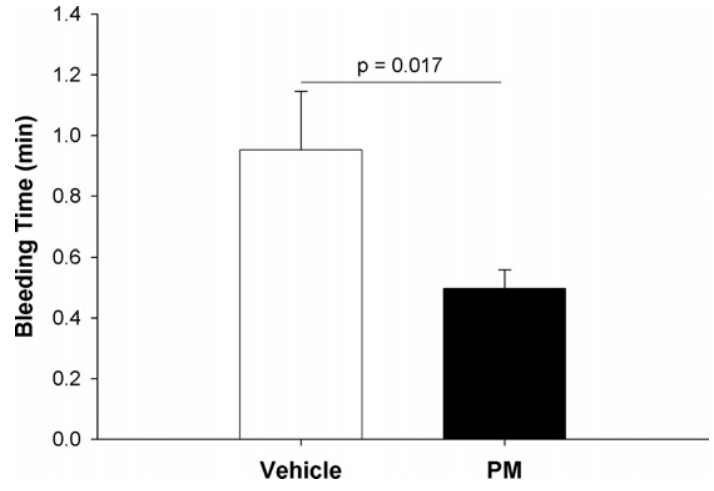

Fig 7. Bleeding times $24 \mathrm{~h}$ after vehicle or PM exposure. Tail-tips were surgically transected $24 \mathrm{~h}$ after exposure and bleeding time was measured. Values for bleeding time represent mean bleeding time \pm $\mathrm{SE}, \mathrm{n}=12$ in each group.

\section{DISCUSSION}

Studies have linked human exposure to air pollution with increased cardiovascular mortality because of ischemic heart disease, heart failure, arrhythmia, and cardiac arrest. ${ }^{13}$ Increases in air pollution have also been associated with an increased incidence of hospitalization for these same cardiovascular complications $24 \mathrm{~h}$ after peak ambient pollution levels. ${ }^{13}$ Populationbased studies by Liao et $\mathrm{al}^{56}$ have shown that shortterm exposure to coarse PM was positively associated with plasma inflammatory and hemostatic risk factors for cardiovascular disease. Although evidence suggesting a link between pollution and hypercoagulability is accumulating, there is still little evidence to suggest that PM directly affects the clotting cascade in otherwise healthy animals. The results of this study provide evidence that pulmonary exposure to ambient PM induces acute-phase inflammation and alters hemostatic factors associated with blood clot formation and resolution.

Multiple observations from this study support the concept that exposure to PM induces a state of hypercoagulability conducive to thrombus formation in healthy animals. The number of circulating platelets, the concentration of sP-selectin, and fibrinogen in plasma were increased by PM exposure (Figs 1 and 3). The amount of TFPI in plasma, which should downregulate the activity of the tissue factor pathway, was reduced by PM exposure (Fig 5). Plasma tPA level was unchanged (Fig 6, A), but plasma PAI-1 level was increased (Fig 6, $B$ ), which is expected to decrease the activity of available tPA. The time for coagulation to occur was decreased after PM exposure, as indicated by shorter bleeding times after tail-tip transection (Fig 7). Thus, PM exposure induced multiple procoagulant changes predicted to contribute to an environment conducive to thrombus formation.

Alterations in platelet number and function play a pivotal role in the pathogenesis of acute coronary syndromes. ${ }^{57,58}$ Increases in platelet number, size, and activity are considered risk factors for MI. ${ }^{59-61}$ Reed et $\mathrm{al}^{15}$ has shown that total platelet numbers were increased in rodents exposed to hardwood smoke by whole-body inhalation. The increase in platelet number observed in response to PM exposure was consistent with these earlier studies, but the increase was small and unlikely to be clinically relevant by itself. Platelet activation has also been shown to be altered with PM exposure. Nemmar et $\mathrm{al}^{20}$ have demonstrated that circulating platelets were directly activated by interacting with diesel exhaust particles. It should be noted that some studies have not demonstrated an increase in circulating platelet number or activity with PM exposure. $^{20,62}$ This discrepancy could be a result of differences in exposure methods, duration of administration, dose administered, time of measurement, or innate characteristics of PM used in those studies. sP-selectin can facilitate procoagulant activity, ${ }^{44,45,63}$ and increased sP-selectin levels have been linked to acute myocardial infarction, peripheral arterial occlusive disease, plaque destabilization, and atrial fibrillation. ${ }^{64-68}$ sP-selectin is typically thought to be an indicator of platelet activation state. However, Burger et $\mathrm{a}^{45}$ have demonstrated that the primary source of circulating P-selectin may be activated endothelial cells. In either case, sP-selectin levels serve as a marker of an activated vasculature/blood interface that would promote thrombus formation.

In contrast to the results in this study, Khandoga et $\mathrm{al}^{69}$ demonstrated that PM administered intravenously did not increase endothelial expression of Pselectin in mice, although sP-selectin was not measured. Their findings may be related to the time of assessment or the route of administration, resulting in a lack of appreciable pulmonary inflammation in their model. ${ }^{13} \mathrm{~A}$ link between sP-selectin levels and the degree of pulmonary inflammation in response to PM exposure is an interesting concept because it suggests that the capacity of PM to alter thrombogenic potential may be linked to a generalized inflammatory condition as opposed to a specific effect of the particles. More studies must be conducted to test this hypothesis.

Increased fibrinogen levels have been associated with the progression of atherosclerotic lesions and are considered a risk factor for future cardiovascular events. ${ }^{47}$ The results of this study (Fig 3) are consistent with human ambient particle exposure studies by Ghio et $\mathrm{al}^{34}$ in which plasma fibrinogen levels were increased $24 \mathrm{~h}$ after particle inhalation. Thus, adminis- 
tration of PM by either inhalation or instillation resulted in increased fibrinogen levels.

Increased TAT complex concentrations within the plasma are indicative of activation of the coagulation pathway. ${ }^{50}$ In human studies, increased TAT levels have been linked to MI, unstable angina, and atrial fibrillation. ${ }^{70}$ TAT concentrations measured $24 \mathrm{~h}$ after PM exposure were not altered compared with control values (Fig 4), indicating that at the time point investigated evidence for activation of the coagulation pathway was not detected. These results are in agreement with those of Nadziejko et al, ${ }^{71}$ who demonstrated that inhaled fine PM did not affect plasma TAT levels in rats at 12 and $24 \mathrm{~h}$ post-exposure.

TFPI is a glycoprotein that is released primarily by activated endothelial cells and acts as a primary inhibitor of clot formation by inhibiting thrombin production. ${ }^{51,52}$ In this study, plasma TFPI was significantly decreased after PM exposure (Fig 5). This report is the first to address the ability of PM to alter TFPI protein expression. Decreased TFPI levels have recently been linked to an increased risk of deep vein thrombosis in humans. ${ }^{72}$

Occlusion of microvessels in vivo is affected by both thrombus formation and resolution. Observations indicate that PM exposure may also affect the resolution of clots through alteration of the fibrinolytic pathway. tPA converts plasminogen to plasmin, which promotes clot lysis. ${ }^{73}$ PAI-1 is the major inhibitor of tPA and thereby promotes clot retention. ${ }^{54}$ Although plasma tPA levels were unaltered, plasma PAI-1 levels were increased significantly, which would be expected to impair fibrinolysis (Fig 6). Increased PAI-1 levels and subsequently impaired fibrinolysis are associated with cardiovascular disease, insulin resistance, and abdominal obesity. ${ }^{54,73,74}$ This study is the first demonstration that PM exposure can alter the expression of inhibitors of both clot formation and resolution in a procoagulant manner.

Hemostasis is a balance between coagulation and fibrinolytic processes. ${ }^{75}$ Therefore, a tail-tip transection was performed as an overall indication of the effect of $\mathrm{PM}$ exposure on hemostasis in vivo. In this study, it was demonstrated that bleeding time was significantly reduced $24 \mathrm{~h}$ after PM exposure (Fig 7). Bleeding time is a function of vascular reactivity, coagulation status, and platelet function. ${ }^{76}$ The lack of significant difference in total blood loss between the experimental and control groups is consistent with the presence of only a mild thrombotic tendency in the PM-exposed animals. In this study, evidence of altered endothelial function includes reduced plasma TFPI, increased sP-selectin, and increased PAI-1 expression. In addition, it was previously demonstrated that aortic relaxation to acetylcho- line is impaired $24 \mathrm{~h}$ after PM exposure. ${ }^{10}$ Platelet number in this model was increased; however, platelet activation was not detected as evidenced by the absence of an increase in platelet/monocyte adhesion determined by flow cytometry. Thus, the reduction in bleeding time observed in this model may be due primarily to endothelial activation and subsequent prothrombotic alterations in coagulation factors responsible for clot formation and resolution. It is important to note that bleeding times have been used extensively to study pharmacologic, pathophysiologic, and genetic alterations in hemostasis in humans and animals. ${ }^{76}$ These results are consistent with studies that have looked directly at clot formation in vivo. Nemmar et $\mathrm{al}^{20} \mathrm{dem}-$ onstrated that intratracheal diesel exhaust particle exposure enhanced arterial and venous thrombus formation in an in vivo endothelial injury model. Likewise, Radomski et al ${ }^{35}$ showed that exposure to nanoparticles resulted in increased thrombosis induced by ferric chloride endothelial injury in rat carotid arteries.

Speculations. Taken together, the results of this study provide evidence that pulmonary exposure to PM alters thrombogenic potential through effects on clot formation and resolution, which may be particularly relevant in a setting of preexisting atherosclerotic disease in which individuals are susceptible to thrombus formation and vessel occlusion. Furthermore, the results define a set of easily measured hemostatic parameters by which particle exposure time courses and particle toxicity may be further investigated.

The authors thank Martina Bainbridge Christie, Mary Cobb, Shaun Reece, Dr. Arthur Bode, Howard Stallings III, Dr. Douglas A. Weidner, Ralph Smith, and Elizabeth Fontenot for technical assistance with this study. This research has been reviewed by the National Health and Environmental Effects Research Laboratory, USEPA, and approved for publication. Approval does not necessarily reflect policy, and mention of trade names or commercial products does not constitute endorsement or recommendation for use.

\section{REFERENCES}

1. Peters A, Dockery DW, Muller JE, Mittleman MA. Increased particulate air pollution and the triggering of myocardial infarction. Circulation 2001;103:2810-5.

2. Peters A, Liu E, Verrier RL, Schwartz J, Gold DR, Mittleman M, et al. Air pollution and incidence of cardiac arrhythmia. Epidemiology 2000;11:11-7.

3. Pope CA III, Burnett RT, Thurston GD, Thun MJ, Calle EE, Krewski D, et al. Cardiovascular mortality and long-term exposure to particulate air pollution: epidemiological evidence of general pathophysiological pathways of disease. Circulation 2004;109:71-7.

4. Kodavanti UP, Moyer CF, Ledbetter AD, Schladweiler MC, Costa DL, Hauser R, et al. Inhaled environmental combustion particles cause myocardial injury in the wistar kyoto rat. Toxicol Sci 2003;71:237-45.

5. Bagate K, Meiring JJ, Gerlofs-Nijland ME, Vincent R, Cassee FR, Borm PJA. Vascular effects of ambient particulate matter 
instillation in spontaneous hypertensive rats. Toxicol Appl Pharmacol 2004;197:29-39.

6. Tzeng HP, Yang RS, Ueng TH, Lin-Shiau SY, Liu SH. Motorcycle exhaust particulates enhance vasoconstriction in organ culture of rat aortas and involve reactive oxygen species. Toxicol Sci 2003;75:66-73.

7. Moyer CF, Kodavanti UP, Haseman JK, Costa DL, Nyska A. Systemic vascular disease in male $\mathrm{B} 6 \mathrm{C} 3 \mathrm{~F} 1$ mice exposed to particulate matter by inhalation: studies conducted by the National Toxicology Program. Toxicol Pathol 2002;30:427-34.

8. Campen MJ, McDonald JD, Gigliotti AP, Seilkop SK, Reed MD, Benson JM. Cardiovascular effects of inhaled diesel exhaust in spontaneously hypertensive rats. Cardiovasc Toxicol 2003;3:35361.

9. Wellenius GA, Batalha JR, Diaz EA, Lawrence J, Coull BA, Katz T, et al. Cardiac effects of carbon monoxide and ambient particles in a rat model of myocardial infarction. Toxicol Sci 2004;80:367-76.

10. Cozzi E, Hazarika S, Stallings HW III, Cascio WE, Devlin RB, Lust RM, et al. Ultrafine particulate matter exposure augments ischemia-reperfusion injury in mice. Am J Physiol Heart Circ Physiol 2006;291:H894-903.

11. Culic V. Acute risk factors for myocardial infarction. Int J Cardiol. In press.

12. Sun Q, Wang A, Jin X, Natanzon A, Duquaine D, Brook RD, et al. Long-term air pollution exposure and acceleration of atherosclerosis and vascular inflammation in an animal model. JAMA 2005;294: 3003-10.

13. Brook RD, Franklin B, Cascio W, Hong Y, Howard G, Lipsett $\mathrm{M}$, et al. Air pollution and cardiovascular disease: a statement for healthcare professionals from the Expert Panel on Population and Prevention Science of the American Heart Association. Circulation 2004;109:2655-71.

14. Delfino RJ, Sioutas C, Malik S. Potential role of ultrafine particles in associations between airborne particle mass and cardiovascular health. Environ Health Perspect 2005;113:934-46.

15. Reed MD, Campen MJ, Gigliotti AP, Harrod KS, McDonald JD, Seagrave JC, et al. Health effects of subchronic exposure to environmental levels of hardwood smoke. Inhal Toxicol 2006; 18:523-39.

16. de Kok TM, Driece HA, Hogervorst JG, Briede JJ. Toxicological assessment of ambient and traffic-related particulate matter: a review of recent studies. Mutat Res 2006;613:103-22

17. Wallington TJ, Kaiser EW, Farrell JT. Automotive fuels and internal combustion engines: a chemical perspective. Chem Soc Rev 2006;35:335-47.

18. Chimonas MA, Gessner D. Airborne particulate matter from primarily geologic, non-industrial sources at levels below National Ambient Air Quality Standards is associated with outpatient visits for asthma and quick-relief medication prescriptions among children less than 20 years old enrolled in Medicaid in Anchorage, Alaska. Environ Res. In press.

19. Salvi S, Blomberg A, Rudell B, Kelly F, Sandstrom T, Holgate ST, et al. Acute inflammatory responses in the airways and peripheral blood after short-term exposure to diesel exhaust in healthy human volunteers. Am J Respir Crit Care Med 1999; 159:702-9.

20. Nemmar A, Hoylaerts MF, Hoet PH, Nemery B. Possible mechanisms of the cardiovascular effects of inhaled particles: systemic translocation and prothrombotic effects. Toxicol Lett 2004;149:243-53.

21. Salvi S, Holgate ST. Mechanisms of particulate matter toxicity. Clin Exp Allergy 1999;29:1187-94.
22. Schulz H, Harder V, Ibald-Mulli A, Khandoga A, Koenig W, Krombach F, et al. Cardiovascular effects of fine and ultrafine particles. J Aerosol Med 2005;18:1-22.

23. Stenfors N, Nordenhall C, Salvi SS, Mudway I, Soderberg M, Blomberg A, et al. Different airway inflammatory responses in asthmatic and healthy humans exposed to diesel. Eur Respir J 2004;23:82-6.

24. Nurkiewicz TR, Porter DW, Barger M, Castranova V, Boegehold MA. Particulate matter exposure impairs systemic microvascular endothelium-dependent dilation. Environ Health Perspect 2004; 112:1299-306.

25. Mukae H, Vincent R, Quinlan K, English D, Hards J, Hogg JC, et al. The effect of repeated exposure to particulate air pollution (PM10) on the bone marrow. Am J Respir Crit Care Med 2001;163:201-9.

26. Sakai M, Sato Y, Sato S, Ihara S, Onizuka M, Sakakibara Y, et al. Effect of relocating to areas of reduced atmospheric particulate matter levels on the human circulating leukocyte count. J Appl Physiol 2004;97:1774-80.

27. Peters A, Frohlich M, Doring A, Immervoll T, Wichmann HE, Hutchinson WL, et al. Particulate air pollution is associated with an acute phase response in men. Results from the MONICAAugsburg Study. Eur Heart J 2001;22:1198-204.

28. Peters A. Particles in the outside air increase the risk of cardiovascular diseases. Gesundheitswesen 2005;67(Suppl 1):S79-85.

29. Sandhu RS, Petroni DH, George WJ. Ambient particulate matter, C-reactive protein, and coronary artery disease. Inhal Toxicol 2005;17:409-13.

30. Verrier RL, Mittleman MA, Stone PH. Air pollution: an insidious and pervasive component of cardiac risk. Circulation 2002;106: $890-2$.

31. Brook RD, Brook JR, Rajagopalan S. Air pollution: the "heart" of the problem. Curr Hypertens Rep 2003;5:32-9.

32. Brook RD, Brook JR, Urch B, Vincent R, Rajagopalan S, Silverman F. Inhalation of fine particulate air pollution and ozone causes acute arterial vasoconstriction in healthy adults. Circulation 2002;105:1534-6.

33. Fabbi P, Ghigliotti G, Brunelli C, Balbi M, Spallarossa P, Rossettin $\mathrm{P}$, et al. Intense lipid peroxidation in premature clinical coronary atherosclerosis is associated with metabolic abnormalities. J Lab Clin Med 2004;143:99-105.

34. Ghio AJ, Hall A, Bassett MA, Cascio WE, Devlin RB. Exposure to concentrated ambient air particles alters hematologic indices in humans. Inhal Toxicol 2003;15:1465-78

35. Radomski A, Jurasz P, onso-Escolano D, Drews M, Morandi M, Malinski T, et al. Nanoparticle-induced platelet aggregation and vascular thrombosis. Br J Pharmacol 2005;146:882-93.

36. Hoff J. Methods of blood collection in the mouse. Lab Animal 2000;29:47-53.

37. Clauss A. Rapid physiological coagulation method in determination of fibrinogen. Acta Haematol 1957;17:237-46.

38. Ravanat C, Freund M, Dol F, Cadroy Y, Roussi J, Incardona F, et al. Cross-reactivity of human molecular markers for detection of prethrombotic states in various animal species. Blood Coagul Fibrinolysis 1995;6:446-55.

39. Leon C, Freund M, Ravanat C, Baurand A, Cazenave JP, Gachet C. Key role of the P2Y(1) receptor in tissue factor-induced thrombin-dependent acute thromboembolism: studies in P2Y(1)knockout mice and mice treated with a P2Y(1) antagonist. Circulation 2001; 103:718-23.

40. Michielsen EC, Diris JH, Hackeng CM, Wodzig WK, Van Dieijen-Visser MP. Highly sensitive immunoprecipitation method for extracting and concentrating low-abundance proteins from human serum. Clin Chem 2005;51:222-4. 
41. Sato K, Taniuchi Y, Kawasaki T, Hirayama F, Koshio H, Matsumoto $\mathrm{Y}$, et al. Comparison of the anticoagulant and antithrombotic effects of YM-75466, a novel orally-active factor Xa inhibitor, and warfarin in mice. Jpn J Pharmacol 1998;78:191-7.

42. Kodavanti UP, Schladweiler MC, Ledbetter AD, Hauser R, Christiani DC, McGee J, et al. Temporal association between pulmonary and systemic effects of particulate matter in healthy and cardiovascular compromised rats. J Toxicol Environ Health A 2002;65:1545-69.

43. Nemmar A, Hoet PH, Dinsdale D, Vermylen J, Hoylaerts MF, Nemery B. Diesel exhaust particles in lung acutely enhance experimental peripheral thrombosis. Circulation 2003;107:1202-8.

44. Andre P. P-selectin in haemostasis. Br J Haematol 2004;126: 298-306.

45. Burger PC, Wagner DD. Platelet P-selectin facilitates atherosclerotic lesion development. Blood 2003;101:2661-6.

46. Michelson AD, Barnard MR, Krueger LA, Valeri CR, Furman MI. Circulating monocyte-platelet aggregates are a more sensitive marker of in vivo platelet activation than platelet surface P-selectin: studies in baboons, human coronary intervention, and acute myocardial infarction. Circulation 2002;104:1533-7.

47. Toss H, Lindahl B, Siegbahn A, Wallentin L. Prognostic influence of increased fibrinogen and C-reactive protein levels in unstable coronary artery disease. FRISC Study Group. Fragmin during instability in coronary artery disease. Circulation 1997; 96:4204-10.

48. Chambers RC, Leoni P, Blanc-Brude OP, Wembridge DE, Laurent GJ. Thrombin is a potent inducer of connective tissue growth factor production via proteolytic activation of proteaseactivated receptor-1. J Biol Chem 2000;275:35584-91.

49. Bock PE, Olson ST, Bjork I. Inactivation of thrombin by antithrombin is accompanied by inactivation of regulatory exosite I. J Biol Chem 1997;272:19837-45.

50. Sommeijer DW, van Oerle R, Reitsma PH, Timmerman JJ, Meijers JC, Spronk HM, et al. Analysis of blood coagulation in mice: pre-analytical conditions and evaluation of a home-made assay for thrombin-antithrombin complexes. Thromb J 2005;3:12.

51. Brodin E, Iversen N, Hansen JB. Impact of native VLDL on tissue factor pathway inhibitor in endothelial cells and interactions between TFPI and lipoprotein lipase. J Lab Clin Med 2006;147:167-73.

52. Walker CP, Royston D. Thrombin generation and its inhibition: a review of the scientific basis and mechanism of action of anticoagulant therapies. Br J Anaesth 2002;88:848-63.

53. Ishii-Watabe A, Uchida E, Mizuguchi H, Hayakawa T. On the mechanism of plasmin-induced platelet aggregation. implications of the dual role of granule ADP. Biochem Pharmacol 2000;59:1345-55.

54. Gils A. The pathophysiological relevance of PAI-1 in cardiovascular diseases and the development of monoclonal antibodies as PAI-1 inhibitors. Verh K Acad Geneeskd Belg 2006;68:179-98.

55. Kung SH, Hagstrom JN, Cass D, Tai SJ, Lin HF, Stafford DW, et al. Human factor IX corrects the bleeding diathesis of mice with hemophilia B. Blood 1998;91:784-90.

56. Liao D, Heiss G, Chinchilli VM, Duan Y, Folsom AR, Lin HM, et al. Association of criteria pollutants with plasma hemostatic/ inflammatory markers: a population-based study. J Expo Anal Environ Epidemiol 2005;15:319-28.

57. Aukrust P, Waehre T, Damas JK, Gullestad L, Solum NO. Inflammatory role of platelets in acute coronary syndromes. Heart 2001;86:605-6.

58. Mueller C, Neumann FJ, Hochholzer W, Trenk D, Zeller T, Perruchoud AP, et al. The impact of platelet count on mortality in unstable angina/non-ST-segment elevation myocardial infarction. Am Heart J 2006;151:1214-7.

59. Weinberger I, Fuchs J, Davidson E, Rotenberg Z. Circulating aggregated platelets, number of platelets per aggregate, and platelet size during acute myocardial infarction. Am J Cardiol 1992;70:981-3.

60. Kilicli-Camur N, Demirtunc R, Konuralp C, Eskiser A, Basaran Y. Could mean platelet volume be a predictive marker for acute myocardial infarction? Med Sci Monit 2005;11:CR387-92.

61. Yip HK, Chang LT, Sun CK, Chen MC, Yang CH, Hung WC, et al. Platelet activity is a biomarker of cardiac necrosis and predictive of untoward clinical outcomes in patients with acute myocardial infarction undergoing primary coronary stenting. Circ J 2006;70:31-6.

62. Pope CA III, Hansen ML, Long RW, Nielsen KR, Eatough NL, Wilson WE, et al. Ambient particulate air pollution, heart rate variability, and blood markers of inflammation in a panel of elderly subjects. Environ Health Perspect 2004;112:339-45.

63. Andre P, Hartwell D, Hrachovinova I, Saffaripour S, Wagner DD. Pro-coagulant state resulting from high levels of soluble P-selectin in blood. Proc Natl Acad Sci USA 2000;97:13835-40.

64. Blann AD, Li-Saw-Hee F, Lip GY, Minamino T, Kitakaze M, Sanada $\mathrm{S}$, et al. Increased membrane and soluble P-selectin in atrial fibrillation. Circulation 1999;100:e86-7.

65. Yu TH, Chua S, Cheng CI, Liu WH, Chiu CA, Yang CH, et al. Concentration of soluble P-selectin and white blood cell counts in infarct coronary arteries in patients with acute myocardial infarction differ from the systemic circulation. Chang Gung Med J 2006;29:169-74.

66. Liu WH, Yang CH, Yeh KH, Chang HW, Chen YH, Chen SM, et al. Circulating levels of soluble P-selectin in patients in the early and recent phases of myocardial infarction. Chang Gung Med J 2005;28:613-20.

67. Woollard KJ, Kling D, Kulkarni S, Dart AM, Jackson S, ChinDusting J. Raised plasma soluble P-selectin in peripheral arterial occlusive disease enhances leukocyte adhesion. Circ Res 2006; 98:149-56.

68. Draz N, Hamdy MS, Gomaa Y, Ramzy AA. Soluble P-selectin is a marker of plaque destabilization in unstable angina. Egypt J Immunol 2003;10:83-7.

69. Khandoga A, Stampfl A, Takenaka S, Schulz H, Radykewicz R, Kreyling W, et al. Ultrafine particles exert prothrombotic but not inflammatory effects on the hepatic microcirculation in healthy mice in vivo. Circulation 2004;109:1320-5.

70. Stegnar M, Vene N, Bozic M. Do haemostasis activation markers that predict cardiovascular disease exist? Pathophysiol Haemost Thromb 2003;33:302-8.

71. Nadziejko C, Fang K, Chen LC, Cohen B, Karpatkin M, Nadas A. Effect of concentrated ambient particulate matter on blood coagulation parameters in rats. Res Rep Health Eff Inst 2002;111:7-29.

72. Dahm A, Van HV, Bendz B, Rosendaal F, Bertina RM, Sandset PM. Low levels of tissue factor pathway inhibitor (TFPI) increase the risk of venous thrombosis. Blood 2003;101:4387-92.

73. Abe Y, Nakamura H, Yoshino O, Oya T, Kimura T. Decreased neural damage after spinal cord injury in tPA-deficient mice. J Neurotrauma 2003;20:43-57.

74. Trost S, Pratley R, Sobel B. Impaired fibrinolysis and risk for cardiovascular disease in the metabolic syndrome and type 2 diabetes. Curr Diab Rep 2006;6:47-54.

75. Ryan KL, Cortez DS, Dick EJ Jr, Pusateri AE. Efficacy of FDA-approved hemostatic drugs to improve survival and reduce bleeding in rat models of uncontrolled hemorrhage. Resuscitation 2006;70:133-44.

76. Lee DH, Blajchman MA. Animal models. In: Michelson AD, ed. Platelets. San Diego, Calif: Academic Press, 2002:357-66. 